\title{
The Impact of Suburbanization on Social Differentiation in Hungary: a Case Study of the Miskolc Agglomeration
}

\author{
Andrea Kristóf ${ }^{A}$ \\ Received: April 6, 2018 | Revised: June 18, 2018 | Accepted: June 19, 2018
}

DOI: $10.5937 / g p 22-17081$

\begin{abstract}
The aim of this paper is to present how the socio-economic processes of the past few years have affected Miskolc (presently the fourth largest city in Hungary) and the nearby suburban settlements with special regard to changes in population, educational attainment, motivations for suburbanization and satisfaction with suburban living conditions. In addition to the analysis of related statistics, the paper reports the results of a residential questionnaire survey, conducted in the suburbs of the Miskolc agglomeration. The paper argues that the suburbanizing process has resulted in the social restructuring of the suburban settlements of the Miskolc agglomeration. Results prove that suburbanization has played an important role in improving educational attainment figures in suburbs, since two-fifths of people involved in suburbanization (according to the questionnaire survey) completed tertiary education, which is higher than the average of Miskolc and the agglomeration. It has been shown that better living conditions (less polluted, less crowded residential areas) have been one of the most important factors for suburbanization in the Miskolc agglomeration, since it has been revealed that the majority of people involved in suburbanization previously lived in one of the crowded housing estates in Miskolc, in the immediate neighborhood of heavily polluting industrial plants. Empirical results also show that suburban residents are least satisfied with job opportunities and their financial position, while they are most satisfied with healthcare services, natural environment and public transport. Finally, it has been found that suburban settlements only provide basic services (e.g. family doctor), thus local residents generally heavily rely on the higher-level services (e.g. banking) of Miskolc.
\end{abstract}

Keywords: agglomerating areas; suburbanization; Miskolc suburbia; settlement groups

\section{Introduction}

Some of the most spectacular aspects of modern urbanization are centralization (agglomeration) and decentralization (suburbanization) taking place around cities. A model of modern urbanization was first published by Leo van Den Berg and his research fellows (Leo van Den Berg et al., 1982), which was adopted in the Hungarian literature by György Enyedi (Enyedi, 1984; Tóth, 2006). Enyedi emphasized the background and causes (e.g. industrial society is followed by a post-industrial one) of the stages of modern urbanization and inspired Hungarian geographers to do research on the demographic (Bajmócy, 2003; Csanádi \& Csizmady, 2002; Kovács \& Tóth, 2003; Kókai, 2006; Váti Kht., 2001), sociogeographic, as well as on the economic and infrastructural aspects (Dövényi, 1999; Hardi, 2012; Kovács, 1999; Schuchmann, 2013) of urbanization in Hungary.

In the past few decades investigating the possible ways to make a distinction between agglomeration and

A University of Nyíregyháza, Institute of Tourism and Geography, Sóstói út 31/B, 4400 Nyíregyháza, Hungary;

kristof.andrea@nye.hu 
suburbanization has become one of the most important research topics of Hungarian geographers (Dövényi, 1999; Enyedi, 1984; Kovács, 1999, 2003; Kristóf, 2017; Timár, 2006, 2009) who primarily focused on the restructuring of the population, the economy and the infrastructure within a particular urban agglomeration. However, most of these studies has so far dealt with agglomerations characterized by dynamic economic growth, such as the agglomerations of Budapest and Györ. A significant shortcoming of research produced over the past half century is that it has not explored properly the social consequences of the processes of agglomeration and suburbanization in one of the largest metropolitan areas of Hungary, the Miskolc agglomeration. That is why one of the major goals of this present paper is to explore how the socio-economic processes of the past decade have affected suburban settlements in the Miskolc agglomeration.

The study focuses on the demographic and social changes of the suburban settlements of the Miskolc agglomeration, as well as migration trends determining suburbanization. In addition to the analysis of related statistics, the paper reports the results of a questionnaire survey, conducted in the suburban settlements of the Miskolc agglomeration, highlighting some characteristics of the suburban population, such as the level of education, motivations for migration and satisfaction with the place of residence.

Specifically, the paper aims to answer the questions as follows:

- How have the former "prestige residential areas" (e.g. neighborhoods dominated by detached houses, or tract houses) of the evolving suburban region integrated into the spatial structure of individual settlements and that of the Miskolc agglomeration?

- What have been the benefits and opportunities, and the drawbacks and conflicts of the suburbanization processes for residents living in the examined settlements?

- Which parts of the transforming suburban relationships can be regarded as successful and which parts of them are problematic, creating conflicts?

- How has the suburban generation's life opportunity, mentality and identity changed?

- All this is important because Western European researchers have made similar results. (Espon 2012)

\section{Theoretical background}

\section{Agglomerations in Hungary}

Research on the evolution of agglomerations and settlement groups in Hungary started approximately sixty years ago. These studies (Fórizs, 1967; Perczel, 1964) have shown that the concentration of socialist productive forces played the most important role in the evolution of agglomerations, however it has also been concluded that the centralized development of infrastructure also supported the formation of agglomerations (Köszegfalvi, 1979). For researchers the most striking features of the development of agglomerations in Hungary at that time were rapid population growth and extensive commuting. The primary source of population growth was migration, since it is widely known that more than one million people left Hungarian villages in the 1950s and 1960s and the majority of them settled down in towns and cities. For instance, more than 200 thousand people migrated into the capital (Budapest) during the 1950 s and 1960s and other cities, such as Pécs and Miskolc also saw more than 30 thousand in-migrants, respectively. The other factor, extensive commuting, was due to rapid industrialization. Statistics show that in 1960 the number of (industrial) commuters was the highest to Budapest followed by Miskolc in the second place.

From the 1970s the restructuring of the settlement network in Hungary accelerated. In addition to the
Budapest agglomeration, the Miskolc-Sajó-Valley and the Lake Balaton agglomerations evolved. Hungarian geographers prioritized research on these agglomerations, nevertheless numerous other urbanizing regions existed in Hungary by that time which were often referred to as unified settlement groups. Out of the 32 settlement formations in Hungary György Köszegfalvi (1979) classified 3 as agglomerations, 5 as agglomerating regions, 3 as urbanizing regions, 8 as small and 8 as large settlement groups surrounding cities, and 5 as twin or triad cities. The Hungarian Central Statistical Office (HCSO) officially identified settlement groups (for the first time at the beginning of the 1980s) on the basis of Köszegfalvi's work (Pálné Kovács \& Rechnitzer, 1982).

By 1996 the HCSO reduced the number of observed settlement formations to 23 , which meant that the number of settlements included in these formations also decreased from 646 to 517. In some cases the nomenclature of these settlement formations also changed. Today the statistical office classifies 613 settlements into one of 23 settlement formations in Hungary (Table 1).

\section{Evolution of the Miskolc agglomeration}

Miskolc is currently the fourth largest city in Hungary, which lies in northeastern Hungary, at the meeting point of the Bükk Mountains and the Cserehát 
Table 1. Settlement formations in Hungary according to the HCSO and the changes in the number of settlements included in them

\begin{tabular}{|l|c|c|c|c|}
\hline \multirow{2}{*}{ Settlement formation } & \multicolumn{3}{|c|}{ Number of settlements in } & Population \\
\cline { 2 - 4 } & 1996 & 2003 & 2014 & 2014 \\
\hline Budapest agglomeration & 79 & 81 & 81 & 2421831 \\
\hline Györ agglomeration & 30 & 29 & 68 & 182776 \\
\hline Miskolc agglomeration & 17 & 13 & 36 & 205626 \\
\hline Pécs agglomeration & 62 & 21 & 41 & 183406 \\
\hline Balaton agglomerating region & 41 & 52 & 52 & 147018 \\
\hline Eger agglomerating region & 8 & 10 & 17 & 77861 \\
\hline Szombathely agglomerating region & 45 & 31 & 52 & 117815 \\
\hline Zalaegerszeg agglomerating region & 44 & 29 & 51 & 87852 \\
\hline Békéscsaba settlement group & 10 & 10 & 9 & 135779 \\
\hline Debrecen settlement group & 18 & 9 & 13 & 267949 \\
\hline Dunaújváros settlement group & - & - & 5 & 59438 \\
\hline Kaposvár settlement group & 13 & 14 & 23 & 84259 \\
\hline Kecskemét settlement group & 18 & 9 & 8 & 133434 \\
\hline Nagykanizsa settlement group & - & - & 24 & 62290 \\
\hline Nyíregyháza settlement group & 12 & 5 & 10 & 148416 \\
\hline Salgótarján settlement group & 19 & 9 & 10 & 50975 \\
\hline Sopron settlement group & 21 & 6 & 12 & 75313 \\
\hline Szeged settlement group & 10 & 12 & 15 & 204301 \\
\hline Székesfehérvár settlement group & 17 & 13 & 35 & 167908 \\
\hline Szekszárd settlement group & 16 & 5 & 10 & 48112 \\
\hline Szolnok settlement group & 11 & 6 & 12 & 101996 \\
\hline Tatabánya settlement group & 15 & 12 & 11 & 86151 \\
\hline Veszprém settlement group & 11 & 10 & 18 & 83708 \\
\hline Total & 517 & 386 & 613 & 5134214 \\
\hline
\end{tabular}

Source: Edited by the author based on http://www.ksh.hu

hills ${ }^{1}$ (the Miskolc Gate and its broader surroundings). From the second half of the $19^{\text {th }}$ century the development of the city accelerated, from the 1880 s it became the center of one of the fastest developing heavy industrial regions of historical Hungary. The city's population increased almost two and a half times between 1870 and 1910, and surrounding settlements, which were formerly autonomous but now they are part of Miskolc, also showed similar population dynamics. The explosive population growth was primarily due to the development of heavy industry. The role and position of Miskolc in the Hungarian settlement network fundamentally changed following the Treaty of Trianon (1920), which set up new borders and reduced the territory of Hungary. Before the Treaty of Trianon Miskolc was only the $12^{\text {th }}$ most populous city in historical Hungary, however, after the treaty it became the $6^{\text {th }}$. After 1920, Miskolc became the leading city of

1 Cserehát is a hilly region which is part of the North Hungarian Mountains. northeastern Hungary in terms of the industry, commerce, finance and culture, since its most important rival Košice became part of Czechoslovakia.

Between the two world wars ever stronger relationships developed among Miskolc and surrounding settlements, which were reflected by the dynamic population growth. The population of the city together with that of Diósgyör grew to over 100 ooo as early as 1941 and it was only a matter of time before the functionally integrated settlements were merged through law ('Greater Miskolc'). The idea of creating 'Greater Miskolc' occurred as early as the turn of the $19^{\text {th }}$ and the $20^{\text {th }}$ centuries, but it became reality only in 1945 , when 3 nearby settlements (Diósgyör, Hejöcsaba and Tapolca) were attached to Miskolc. The area and population of 'Greater Miskolc' increased further in 1950, when another three settlements (Görömböly, Hámor and Szirma) were attached to its area, thus Miskolc became the second largest city in Hungary.

After the Second World War industrialization became the most important goal of economic policy in 
Hungary which created favourable circumstances for the development of the city, since Miskolc had long been an important industrial centre in northeastern Hungary. As a result, during the socialist era the development of Miskolc was prioritized and the city also received distinguished political attention in Hungary. Meanwhile the city experienced significant population growth, since more than 30 thousand (30 479) people migrated to Miskolc between 1949 and 1960. The extensive industrial growth of Miskolc was coupled with a geographical expansion as well, many settlements were attached to the city between 1950 and 1981 thus Miskolc had become one of the largest (area: $224 \mathrm{~km}^{2}$ ) industrial cities of Hungary.

Meanwhile numerous attempts were made by researchers to delimit the area of the Miskolc agglomeration and to identify the settlements belonging to it. For instance, Fórizs (1967) grouped 35 settlements into the Miskolc settlement group based on four factors (healthcare, secondary education, retailing, and industrial commuters). Other researchers identified the area of the Miskolc agglomeration according to complex indicators (Szántó, 1979; Süli-Zakar, 1989). Lukács and Perger (1975) identified the Miskolc agglomeration on the basis of 23 indicators (e.g. concentration of productive forces, population and supply of services, etc.). Köszegfalvi (1979) identified Miskolc and the nearby settlements as an agglomeration, which was later adopted by the HCSO as well. Since then Miskolc and the nearby settlements have officially been recognized as one of the agglomeration of Hungary. According to the HCSO the Miskolc agglomeration comprised 17 settlements in 1996, which number was reduced to 13 in 2003 due to changes in methodology. The most recent (Tóth, 2014) delimitation of the Miskolc agglomeration by the HCSO includes 36 settlements (Figure 1).

\section{Methodology}

To explore the impact of suburbanization on the society of the Miskolc agglomeration, the study had to be delimited first. It would have been quite obvious to use the area of the Miskolc agglomeration as delimited by the HCSO as a study area, which currently consists of 36 settlements, however for the purpose of the study this group of settlements would not have been adequate, since the statistical office delimits the agglomeration on the basis of workforce commuting and not on suburbanization processes. As a result, those settlements had to be selected for study within the agglomeration, which were the most heavily affected by suburbanization. To identify these settlements, the relevant literature was reviewed, statistical data analysis was performed (indicators used by the HCSO to delimit agglomerations were applied and settlements were regarded as suburban when the values of these indicators were higher than that of the Miskolc agglomeration and Borsod-Abaúj-Zemplén county) and in-person interviews were conducted with prominent local people (e.g. mayors, notaries and head teachers). As a result of these investigations eleven settlements were identified as heavily involved in suburbanization around Miskolc: Mályi, Kistokaj, Onga, Felsőzsolca, Nyékládháza, Szirmabesenyö, Arnót, Bükkaranyos, Bükkszentkereszt, Kisgyőr and Alsózsolca (Figure 1). However, further research and on-site studies revealed that one of these settlements (Alsózsolca) cannot be regarded as a 'real' suburban settlement, since suburban social and economic processes did not play a decisive role here between 1990 and 2011, so this settlement was excluded from further investigations (Kristóf, 2017b).
In the next phase of the research statistical data on the demographics (e.g. changes in population, level of education, etc.) and infrastructure of the selected settlements were gathered and a questionnaire was designed to provide information that was not included in statistics. The questionnaire, was based on Günter Herfert's work (Brake et al., 2001), which was later modified by Dövényi and Kovács (2006). The final version of the questionnaire comprised 34 open and closed questions concerning the changes in local communities due to suburbanization, the composition and motivations of people involved in suburbanization, the integration of new families into the local society, as well as the changing geographical pattern of services used by newcomers. After testing the questionnaire, the survey was conducted from February 2016 to June 2016. During the survey paper-based questionnaires were used that were completed by personal interviews. Participation in the survey was voluntary and anonymous, results were processed and analyzed by using SPSS software. At the end of the research a total of 975 completed questionnaires were obtained. Table 2 shows the number of completed questionnaires in each settlement.

As Table 2 shows the number of questionnaires was not equally distributed among settlements. The reason for this was that interviews conducted with prominent local people revealed that people having been involved in suburbanization (i.e. newcomers) are geographically not evenly distributed in the examined settlements, but they live in smaller or larger communities concentrating in a few streets or neighbourhoods. As a result, stratified sampling 


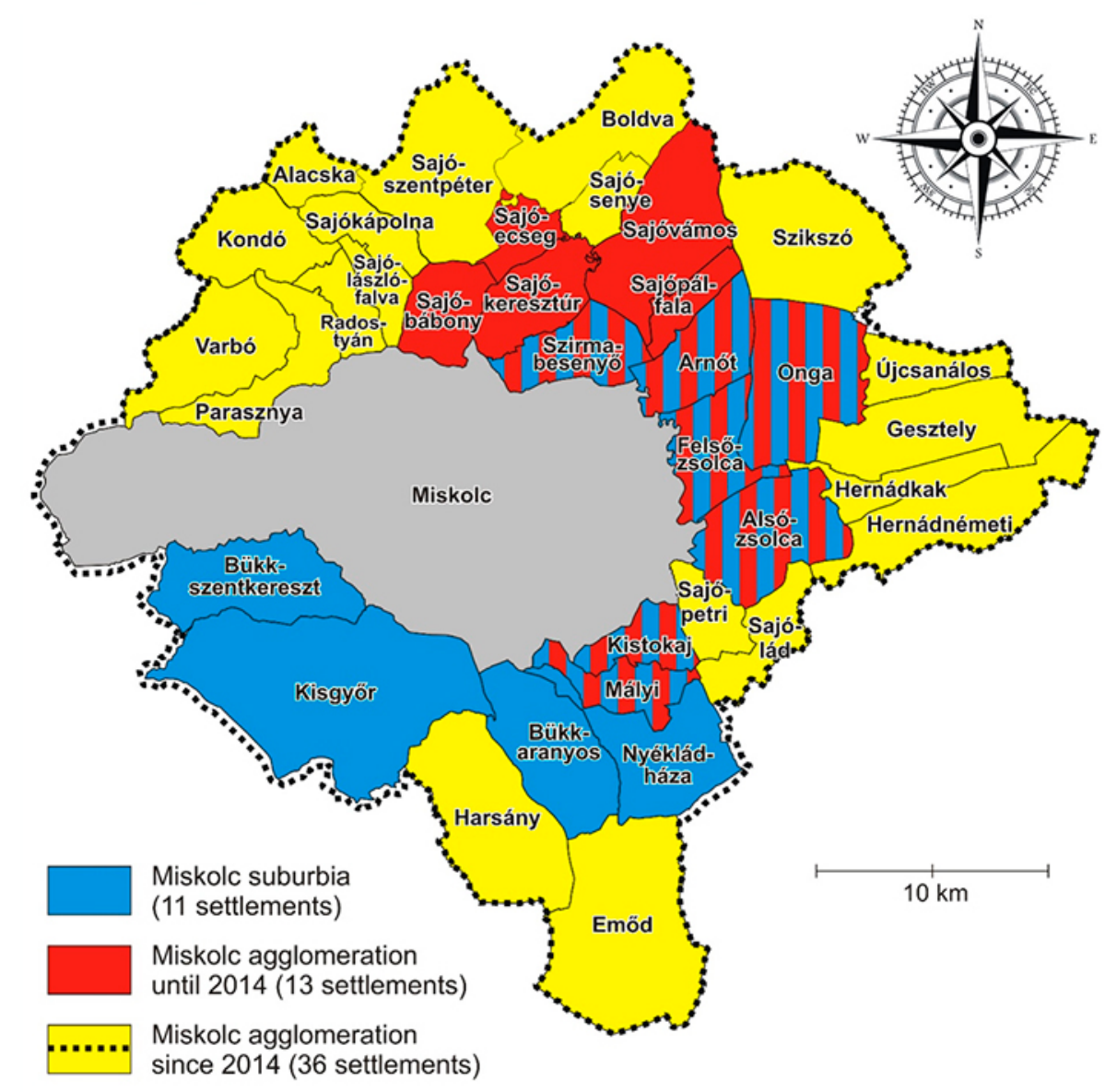

Figure 1. Territorial changes of the Miskolc agglomeration and settlements of the Miskolc suburbia (2003-2015)

Source: Edited by the author based on the 2001 and 2011 national censuses

Table 2. Number of completed questionnaires by settlements

\begin{tabular}{|l|c|c|c|}
\hline Settlement & $\begin{array}{c}\text { Number of } \\
\text { completed } \\
\text { questionnaires }\end{array}$ & $\begin{array}{c}\text { Population } \\
\text { (2015) }\end{array}$ & $\begin{array}{c}\text { Completed questionnaires } \\
\text { as a percentage of the total } \\
\text { population (\%) }\end{array}$ \\
\hline Arnót & 161 & 2387 & 7 \\
\hline Bükkaranyos & 15 & 1499 & 1 \\
\hline Bükkszentkereszt & 54 & 1179 & 5 \\
\hline Felsőzsolca & 156 & 6486 & 2 \\
\hline Kisgyőr & 48 & 1677 & 3 \\
\hline Kistokaj & 132 & 2083 & 3 \\
\hline Mályi & 102 & 3929 & 1 \\
\hline Nyékládháza & 54 & 4865 & 2 \\
\hline Onga & 166 & 4764 & 3 \\
\hline Szirmabesenyő & 87 & 4111 & 3 \\
\hline Total & 975 & 38586 & 3 \\
\hline
\end{tabular}

Source: edited by the author (data on population: HCSO)

was applied, so residents of the settlements selected for study were not randomly asked, but respondents were selected from only those neighbourhoods where the proportion of newcomers was the highest. In addition, the percentage of suburban resi- dents covered by the survey varied from settlement to settlement, that is, suburbanite samples were not equally representative of analyzed settlements. The percentage of suburbanites completing the survey was the highest in Onga (52.5\%) and the lowest in 
Bükkaranyos (19.5\%). As a result the number of settlement questionnaires was not proportional to the population of each settlement and respondents aged 30 and over were overrepresented due to the nature of the investigation. Thus, it is highly important to emphasize that the sample is unrepresentative of the total population of the suburban settlements so re- sults should be interpreted with caution. However, it should also be mentioned that sample is representative of the people involved in suburbanization, since the survey covered 975 households (app. 1700 people), which accounts for more than $20 \%$ of the estimated number of people (6-8 thousand) involved in suburbanization around Miskolc between 1990 and 2011.

\section{Results}

\section{Migration and segregation}

One of the basic characteristic features of population concentration related to modern urbanization is migration, which necessarily generates social disparities among and within settlements.

It was already observable earlier that low and high socioeconomic groups tended to be geographically segregated (e.g. in city agglomerations), however, it was not until the regime change that this process occurred and became a justified research area in socialist countries (including Hungary as well). I agree with the opinion of researchers in this field who claim that suburbanization intensified this process, resulting in (according to public judgement) both positive (e.g. gated communities) and negative (e.g. ghettos) consequences (Csanádi \& Csizmady, 2005; Miskolc ITS, 2013; Perczel, 2003; ; Ladányi \& Szelényi, 1997).

It is a peculiarity of Miskolc that, due to the residents moving out of housing estates (e.g. Avas, which used to be a higher status residential area) and to the declining prestige of inner city neighborhoods, the social structure of Miskolc was disrupted in fact on an almost unprecedented scale as compared to previous periods. As a result of this process groups of the elite started to segregate into new neighborhoods (e.g. Avasalja, Berekalja, Egyetemváros, etc.). The emergence of ghetto district within Miskolc (e.g. the socalled 'Numbered streets', Lyukó valley, etc.) was also

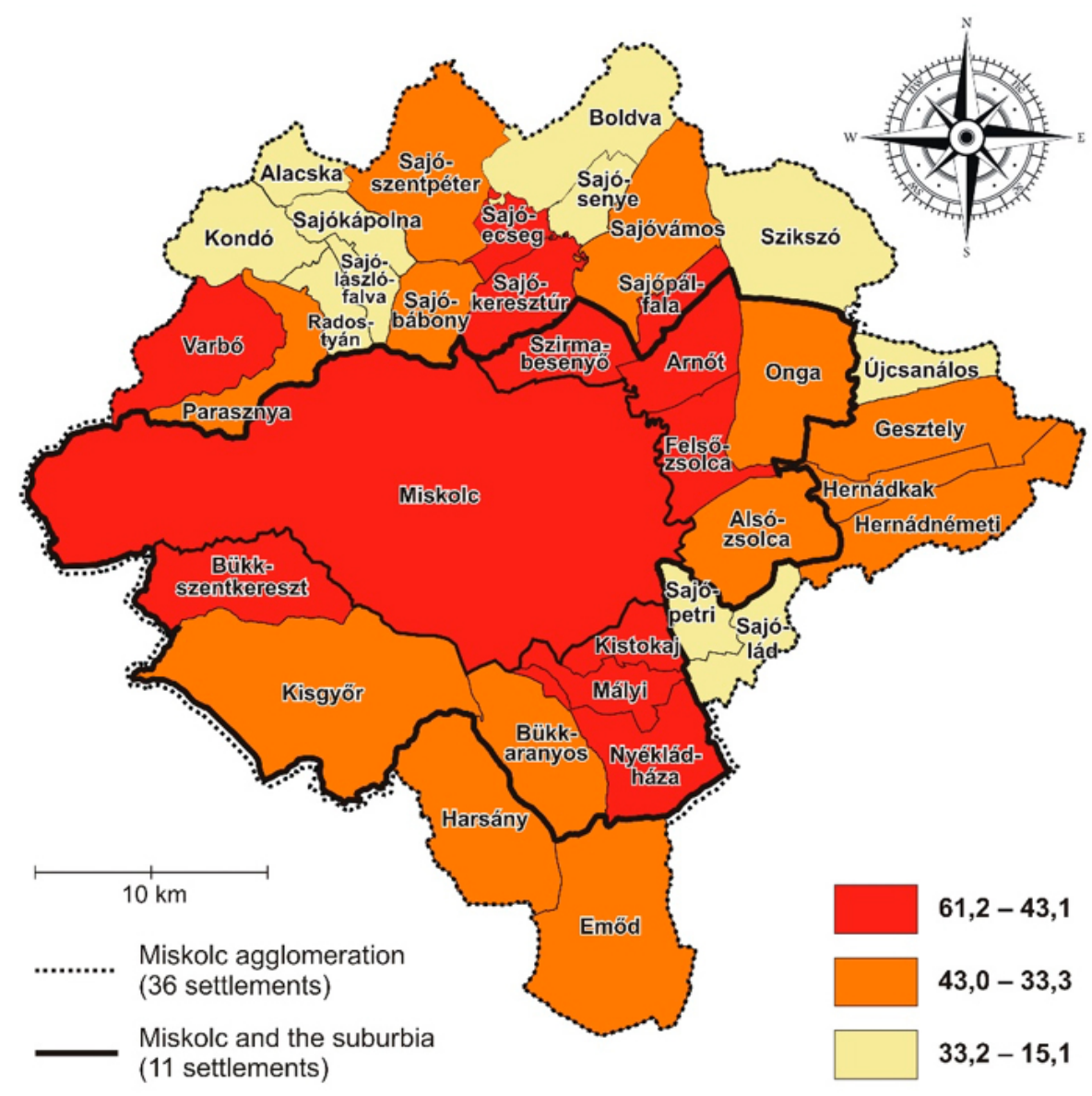

Figure 2. Share of the population with secondary education aged 18 or above (2011) Source: Edited by the author based on HCSO data 


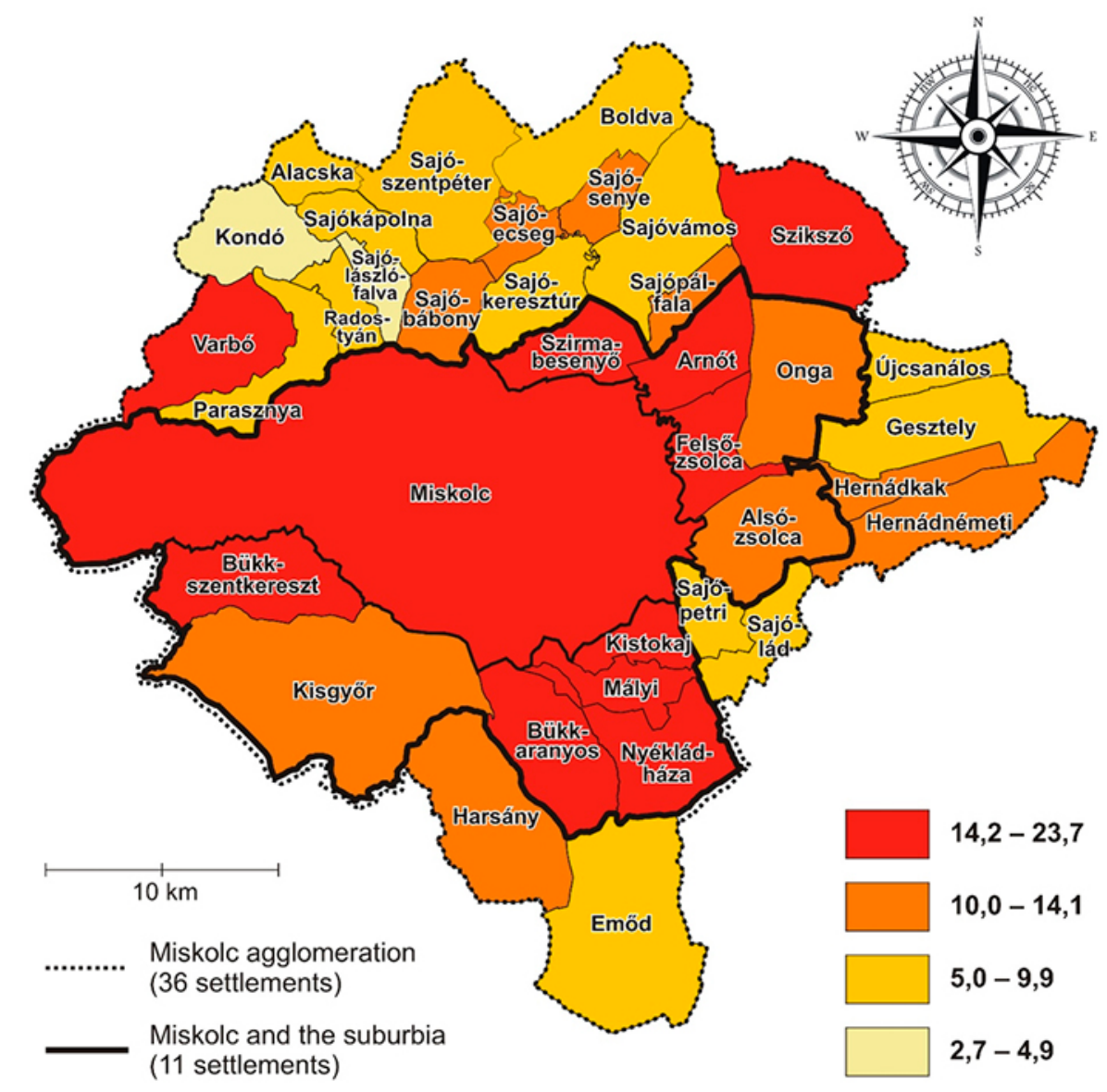

Figure 3. Share of the population with tertiary education aged 25 or above (2011) Source: Edited by the author based on HCSO data

intensified by suburban migratory trends. The process markedly changed and polarized the suburban settlements of the Miskolc agglomeration as well (Figure 2-3).

On the one hand, the role of small settlements in the Bükk Mountains (e.g. Kisgyőr, Bükkszentkereszt, etc.) in concentrating the elite became stronger. On the other hand, there also emerged settlements especially near the administrative borders of Miskolc with favorable economic and transport conditions (e.g. Mályi, Kistokaj, Szirmabesenyő, etc.), which also became the focal points of the new elite with high status residential areas and gated communities. The concentration of low socioeconomic groups also became stronger, with one of the results of these processes being that a contiguous eastern slum region (e.g. Gesztely, Hernádkak, Alsózsolca, Újcsanálos, etc.) emerged within the Miskolc agglomeration characterized by the marked presence of ethnic minorities. (Roma people had already been living in the suburbs before the 1990s, however, in the past 25 years their number has increased at a faster rate than what would be expected on the basis of their natural increase, which implies that their number was also increased by Roma people moving out of Miskolc.)
The low and high socioeconomic groups of Miskolc have been significantly different regarding the directions of their movements, which augmented the segregation within and between the suburban settlements.

Statistical data indicated that in some suburban settlements (e.g. Felsőzsolca, Mályi, Kistokaj, etc.) the number of people with higher education level increased dynamically - surpassing the county and agglomeration means (Table 3).

Statistical data and questionnaires have revealed that families moving out of Miskolc did not have outstanding incomes or significant savings, therefore they did not have enough financial resources to move to a higher quality dwelling within Miskolc. Based on empirical research it can be concluded that a significant portion of out-movers was attracted by the favorable environmental and transport conditions of settlements, low property prices and by benefits offered by local governments (e.g. cheap plots; tax breaks).

These facts also underpin one of the peculiarities of the society of the Miskolc suburbia, namely that the majority of suburban generations belong to the lower middle class which is more vulnerable than other layers of the Hungarian society in terms of social (e.g. integration, local ties, etc.) and economic conditions 
Table 3. Education level of respondents

\begin{tabular}{|l|c|c|c|c|c|c|c|c|}
\hline \multirow{2}{*}{ Settlement } & \multicolumn{4}{|c|}{ Women (\%) } & \multicolumn{4}{c|}{ Men (\%) } \\
\cline { 2 - 11 } & $\begin{array}{c}\text { technical } \\
\text { school }\end{array}$ & $\begin{array}{c}\text { secondary } \\
\text { voc. sch. }\end{array}$ & $\begin{array}{c}\text { grammar } \\
\text { school }\end{array}$ & $\begin{array}{c}\text { university or } \\
\text { college deg. }\end{array}$ & $\begin{array}{c}\text { technical } \\
\text { school }\end{array}$ & $\begin{array}{c}\text { secondary } \\
\text { voc. sch. }\end{array}$ & $\begin{array}{c}\text { grammar } \\
\text { school }\end{array}$ & $\begin{array}{c}\text { university or } \\
\text { college deg. }\end{array}$ \\
\hline Arnót & 12.5 & 35.4 & 14 & 37.5 & 4.9 & 29.5 & 18 & 47.5 \\
\hline Szirmabesenyő & 2.1 & 32.6 & 6.5 & 52.1 & 30.7 & 15.3 & 2.5 & 51.2 \\
\hline Felsőzsolca & 8.8 & 26.4 & 11.7 & 52.9 & 16.6 & 27.7 & 22.2 & 38.8 \\
\hline Kisgyör & 2.9 & 8.8 & 8.8 & 79.4 & 0 & 25 & 0 & 75 \\
\hline Bükkaranyos & 16.6 & 0 & 0 & 83.3 & 0 & 33.3 & 33.3 & 33.3 \\
\hline Bükkszentkereszt & 3.2 & 38.7 & 29 & 29 & 1 & 5 & 15 & 50 \\
\hline Kistokaj & 4.16 & 29.1 & 37.5 & 29.1 & 16.6 & 16.6 & 1.8 & 1.8 \\
\hline Nyékládháza & 8.3 & 16.6 & 33.3 & 41.6 & 0 & 33.3 & 0 & 66.6 \\
\hline Mályi & 5.3 & 25 & 29.6 & 37.5 & 10 & 20 & 20 & 50 \\
\hline Onga & 9.5 & 19 & 20 & 45.7 & 8.1 & 40.9 & 16.3 & 34.4 \\
\hline Total (\%) & 8 & 26.8 & 20.7 & 44.5 & 10.5 & 28.2 & 18.6 & 42.9 \\
\hline
\end{tabular}

Source: Edited by the author based on questionnaire survey

(e.g. financial crisis, problems concerning the repayment of foreign currency loans, unemployment). This is particularly true of disadvantaged social groups including lower educated, low income and unemployed people as well as the Roma.

The financial and economic recession reaching Hungary too, the credit crisis and the social aspects of nonperforming loans (e.g. indebtedness, unemployment, impoverishment, etc.) changed the processes of mobility in the agglomerations of Hungarian cities as well, of which hardly any information exists except for the Budapest agglomeration. In fact, the uncertainty caused by the financial and economic crisis may decelerate or accelerate migratory movements in the future. However, such studies have not yet been carried out in the Miskolc agglomeration, therefore the degree to which the society is affected by this process both vertically and horizontally is unknown.

Based on the survey, it has been shown that the significant increase in the costs associated with the suburban way of life, the apathy of the suburban generation, the deterioration of the former "prestige living spaces", and the social effects of the financial-economic crisis all have contributed to the decline of the

Table 4. Population, natural increase and net migration rate of the Miskolc agglomeration and suburbia (1990-2015)

\begin{tabular}{|c|c|c|c|c|c|c|c|c|c|c|}
\hline \multirow[t]{2}{*}{ Settlements } & \multicolumn{2}{|c|}{$1980-1990$} & \multirow{2}{*}{$\frac{1990}{3 *}$} & \multicolumn{2}{|c|}{$1990-2001$} & \multirow{2}{*}{$\frac{2001}{3^{*}}$} & \multicolumn{2}{|c|}{ 2001-2011 } & \multirow{2}{*}{$\frac{2011}{3 *}$} & \multirow{2}{*}{$\begin{array}{c}2015 \\
3^{*}\end{array}$} \\
\hline & $1^{*}$ & $2 *$ & & $1^{*}$ & $2^{*}$ & & $1^{*}$ & $2^{*}$ & & \\
\hline Miskolc & 1487 & -13148 & 196442 & -6785 & -5532 & 184125 & -8425 & -7946 & 167754 & 159554 \\
\hline Miskolc agglomeration & 2927 & -1253 & 92719 & 1058 & 3674 & 97451 & -1764 & -1475 & 94212 & 92347 \\
\hline \multicolumn{11}{|c|}{ of which the settlements of the suburbia: } \\
\hline Alsózsolca & 308 & -175 & 5723 & 355 & -34 & 6044 & 161 & -439 & 5766 & 5606 \\
\hline Arnót & 170 & 352 & 2082 & 107 & 368 & 2557 & 34 & 6 & 2597 & 2387 \\
\hline Bükkaranyos & -39 & -10 & 1122 & 16 & 255 & 1393 & 30 & 25 & 1448 & 1499 \\
\hline Bükkszentkereszt & 21 & -22 & 1374 & -96 & -4 & 1274 & -85 & 17 & 1206 & 1179 \\
\hline Felsőzsolca & 368 & 446 & 6939 & 193 & -105 & 7027 & 58 & -472 & 6613 & 6486 \\
\hline Kisgyör & 7 & -67 & 1572 & -18 & 55 & 1609 & -39 & 72 & 1642 & 1677 \\
\hline Kistokaj & 39 & 205 & 1489 & 9 & 370 & 1868 & -27 & 237 & 2078 & 2083 \\
\hline Mályi & 168 & 685 & 3353 & 4 & 795 & 4152 & -72 & 44 & 4124 & 3929 \\
\hline Nyékládháza & 57 & 185 & 4432 & -67 & 541 & 4906 & -204 & 321 & 5023 & 4865 \\
\hline Onga & 213 & 213 & 4042 & 278 & 441 & 4761 & 58 & 39 & 4858 & 4764 \\
\hline Szirmabesenyő & 144 & -77 & 4836 & -123 & 16 & 4729 & -238 & -53 & 4438 & 4111 \\
\hline Total & 1456 & 1735 & 36964 & 658 & 2698 & 40320 & -324 & -203 & 39793 & 38586 \\
\hline
\end{tabular}

*1 natural increase, 2 net migration rate (the difference between the number of in-migrants and out-migrants over the examined period), 3 population

Source: edited by the author based on TeIR and HCSO-TSTAR data 
rate of social strata which prefer and are able to take the suburban way of live (Table 4).

\section{Motivations behind moving out of Miskolc to suburban settlements}

Social and economic transformations related to the regime change strongly affected property assets in Hungary, the prices of rented dwellings formerly owned by the state or city councils increased (Csanádi et al., 2010).

By selling these dwellings families living in blocks of flats could create a financial basis for moving home and realizing the dream of the middle class: buying a detached house (Csanádi \& Csizmady, 2002). The most important motivation for people moving out of cities (which started as a sporadic phenomenon, but later became widespread) is generally associated with the negative aspects of urban life (e.g. environmental pollution, crowdedness, alienation, etc.), however, these negative elements were not or just scarcely present in Hungarian cities. However, the conditions of Miskolc were peculiar in this respect as well, since during the years of the regime change $60 \%$ of its residents lived in blocks of flats in the immediate neighbourhood of heavily polluting industrial plants (e.g. Ironworks of Diósgyőr, etc.). The results of the questionnaire survey prove that inadequate living conditions greatly contributed to suburbanization, since the significant majority of people moving out of Miskolc formerly lived in blocks of flats (Table 5).

Data on Bükkszentkereszt, Szirmabesenyő, Kistokaj and Kisgyör indicate that the simple process of moving from blocks of flats to detached houses was not the only feature of suburbanization around Mis- kolc. For the more affluent generations, paying particular attention to environmental conditions, moving out of Miskolc was also a qualitative change, since they moved to settlements of high prestige, despite the fact that they had to accept the disadvantages of lack of transport and other infrastructure in favor of having a bigger house and garden. The dominant majority of the new inhabitants of the suburban region arrived from the crowded blocks of flats in Miskolc.

\section{The suburban society's satisfaction with its place of residence}

Last but not least, respondents were asked to tell their opinions on living conditions in suburbs. Naturally, subjective factors (such as personal characteristics, financial status) play an important role in one's level of satisfaction with their residential environment, however, the survey focused especially on respondents' perceived satisfaction with quasi objective factors (such as income level or public transport). The questionnaire measured the level of satisfaction with eleven pre-given factors on a five-grade scale (Figure 4).

Results show that suburban residents are least satisfied with job opportunities (2.3) and their financial position (2.6), while they are most satisfied with healthcare services (3.6), the natural environment (3.7) and public transport (3.9). Thus, it can be stated that a significant portion of people involved in suburbanization was attracted by the favorable environmental and transport conditions of suburban settlements, low property prices and by benefits offered by local governments.

We should not forget that the availability of services may also influence the level of satisfaction with

Table 5. Former dwellings of people moving out of Miskolc

\begin{tabular}{|c|c|c|c|c|c|c|c|c|}
\hline \multirow[b]{3}{*}{ Settlement } & \multicolumn{8}{|c|}{ Former dwellings (\%) } \\
\hline & \multicolumn{3}{|c|}{ by ownership } & \multicolumn{5}{|c|}{ by type } \\
\hline & private & rented & $\begin{array}{c}\text { local } \\
\text { government }\end{array}$ & $\begin{array}{l}\text { detached } \\
\text { house }\end{array}$ & $\begin{array}{l}\text { terraced } \\
\text { house }\end{array}$ & $\begin{array}{l}\text { block of flats } \\
\text { (five stories } \\
\text { or less) }\end{array}$ & $\begin{array}{c}\text { block of flats } \\
\text { (six stories or } \\
\text { more) }\end{array}$ & $\begin{array}{l}\text { Brick } \\
\text { block of } \\
\text { flats }\end{array}$ \\
\hline Arnót & 67.7 & 19.8 & 12.4 & 20.4 & 9.9 & 39.7 & 19.8 & 9.9 \\
\hline Szirmabesenyő & 77 & 14.9 & 8.04 & 44.8 & 4.59 & 12.6 & 19.5 & 18.3 \\
\hline Felsőzsolca & 89.7 & 5.7 & 4.4 & 30.7 & 2.5 & 26.2 & 34.6 & 5.7 \\
\hline Kisgyőr & 77 & 10.4 & 12.5 & 10.4 & 6.2 & 29.1 & 39.5 & 14.5 \\
\hline Bükkaranyos & 80 & 1 & 2 & 2 & 1 & 4 & 5 & 3 \\
\hline Bükkszentkereszt & 83.3 & 7 & 2 & 29 & 5 & 15 & 3 & 2 \\
\hline Kistokaj & 81 & 11 & 14 & 35 & 18 & 34 & 41 & 4 \\
\hline Nyékládháza & 77.7 & 5 & 7 & 12 & 3 & 19 & 17 & 3 \\
\hline Mályi & 100 & 1 & 1 & 15 & 8 & 41 & 32 & 6 \\
\hline Onga & 113 & 38 & 15 & 26 & 21 & 73 & 36 & 10 \\
\hline Total & 772 & 122 & 81 & 244 & 83 & 316 & 256 & 76 \\
\hline
\end{tabular}

Source: Edited by the author based on questionnaire survey 
5,0

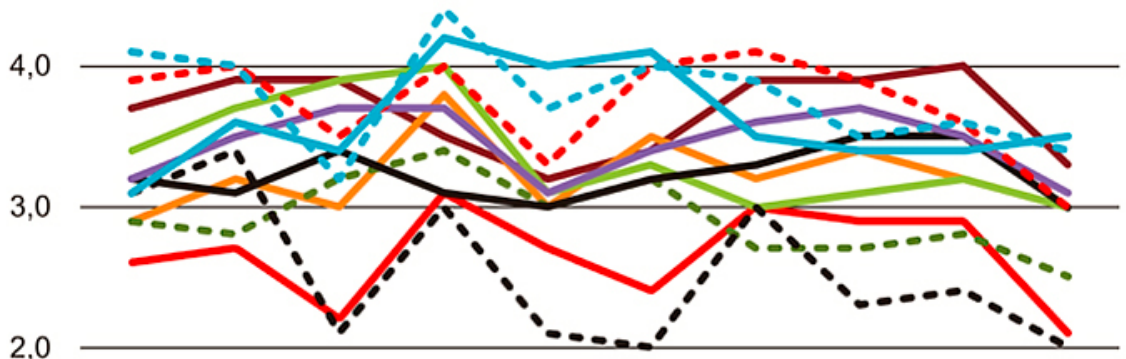

1,0
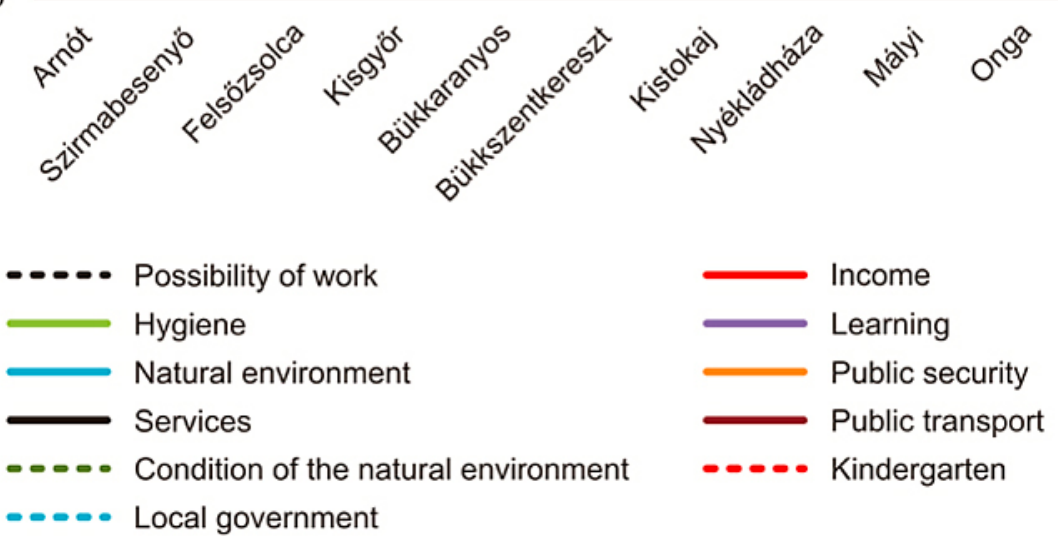

Figure 4. Respondents' level of satisfaction with living conditions in suburbs Source: edited by the author based on questionnaire survey

local living conditions. Therefore, the questionnaire survey was designed to measure the use of services by suburban residents. Respondents had to tell whether they used given services in their place of residence (that is locally) or in Miskolc (Table 6 and 7 ).
Results show that suburban settlements only provide basic services (e.g. family doctor, pharmacy), thus local residents generally heavily rely on the higher-level services (e.g. banking, shopping) of Miskolc.

Table 6. Percentage of respondents using local services

\begin{tabular}{|c|c|c|c|c|c|c|c|c|c|c|c|c|}
\hline \multirow[b]{2}{*}{ Settlement } & \multicolumn{11}{|c|}{ In place (\%) } & \multirow[b]{2}{*}{ Average } \\
\hline & 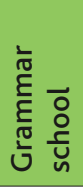 & 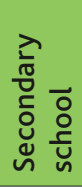 & 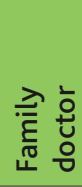 & 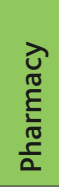 & 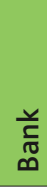 & 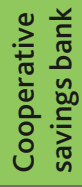 & 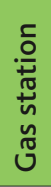 & 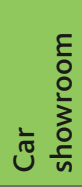 & 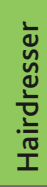 & 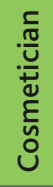 & 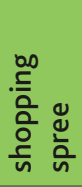 & \\
\hline Arnót & 30 & 0 & 84 & 68 & 1 & 2 & 4 & 35 & 39 & 31 & 0 & 27 \\
\hline Szirmabesenyő & 41 & 0 & 78 & 53 & 0 & 18 & 11 & 8 & 11 & 9 & 0 & 21 \\
\hline Felsőzsolca & 22 & 4 & 76 & 73 & 4 & 10 & 6 & 11 & 17 & 16 & 1 & 22 \\
\hline Kisgyör & 25 & 0 & 56 & 40 & 0 & 0 & 0 & 0 & 25 & 25 & 0 & 16 \\
\hline Bükkaranyos & 27 & 0 & 60 & 0 & 0 & 0 & 0 & 0 & 0 & 0 & 0 & 8 \\
\hline Bükkszentkereszt & 37 & 0 & 89 & 72 & 0 & 4 & 0 & 11 & 52 & 30 & 0 & 27 \\
\hline Kistokaj & 24 & 0 & 59 & 61 & 2 & 2 & 9 & 12 & 32 & 26 & 0 & 21 \\
\hline Nyékládháza & 30 & 0 & 78 & 65 & 7 & 22 & 41 & 22 & 33 & 26 & 0 & 29 \\
\hline Mályi & 18 & 0 & 71 & 58 & 0 & 0 & 0 & 3 & 15 & 5 & 0 & 15 \\
\hline Onga & 33 & 0 & 67 & 32 & 0 & 35 & 0 & 14 & 59 & 25 & 0 & 24 \\
\hline Average & 29 & 0 & 72 & 52 & 1 & 9 & 7 & 12 & 28 & 19 & 0 & 21 \\
\hline
\end{tabular}

Source: Edited by the author based on questionnaire survey 
Table 7. Percentage of respondents using services in Miskolc

\begin{tabular}{|c|c|c|c|c|c|c|c|c|c|c|c|c|}
\hline \multirow[b]{2}{*}{ Settlement } & \multicolumn{11}{|c|}{ In Miskolc (\%) } & \multirow[b]{2}{*}{ Average } \\
\hline & 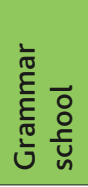 & 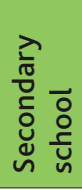 & 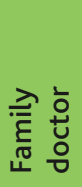 & $\begin{array}{l}\text { ত̃ } \\
\stackrel{\pi}{E} \\
\frac{5}{\pi} \\
\frac{c}{\alpha} \\
\end{array}$ & 弟 & 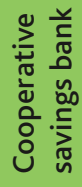 & 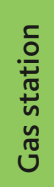 & 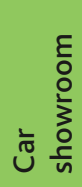 & 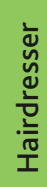 & 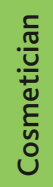 & 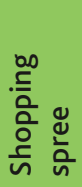 & \\
\hline Arnót & 36 & 73 & 16 & 32 & 72 & 48 & 48 & 29 & 29 & 26 & 86 & 45 \\
\hline Szirmabesenyő & 53 & 41 & 22 & 47 & 55 & 14 & 18 & 18 & 20 & 20 & 32 & 31 \\
\hline Felsőzsolca & 24 & 33 & 24 & 27 & 45 & 8 & 42 & 33 & 23 & 18 & 28 & 28 \\
\hline Kisgyör & 21 & 29 & 44 & 60 & 58 & 21 & 54 & 46 & 42 & 25 & 33 & 39 \\
\hline Bükkaranyos & 40 & 27 & 40 & 100 & 67 & 53 & 67 & 67 & 67 & 67 & 33 & 57 \\
\hline Bükkszentkereszt & 26 & 33 & 11 & 28 & 67 & 19 & 63 & 44 & 7 & 11 & 33 & 31 \\
\hline Kistokaj & 21 & 45 & 41 & 39 & 56 & 27 & 55 & 45 & 27 & 24 & 33 & 38 \\
\hline Nyékládháza & 11 & 19 & 22 & 35 & 48 & 7 & 30 & 7 & 15 & 11 & 33 & 22 \\
\hline Mályi & 31 & 29 & 29 & 42 & 14 & 1 & 13 & 14 & 12 & 4 & 91 & 25 \\
\hline Onga & 46 & 82 & 33 & 68 & 52 & 13 & 50 & 27 & 41 & 43 & 89 & 49 \\
\hline Average & 31 & 41 & 28 & 48 & 53 & 21 & 44 & 33 & 28 & 25 & 49 & 37 \\
\hline
\end{tabular}

Source: Edited by the author based on questionnaire survey

\section{Conclusions}

This paper has attempted to explore some aspects of the restructuring society in the suburbs of Miskolc with special regard to changes in population, educational attainment, motivations for suburbanization and satisfaction with suburban living conditions. One of the main conclusions of the study is that suburbanization has significantly contributed to the social restructuring of the suburban settlements of the Miskolc agglomeration in the past few decades. Results prove that suburbanization has played an important role in improving educational attainment figures in suburbs, since two-fifths of people involved in suburbanization (according to the questionnaire survey) completed tertiary education, which is higher than the average of Miskolc and the agglomeration. It has been shown that better living conditions (less polluted, less crowded residential areas) have been one of the most important factors for suburbanization in the Miskolc agglomeration, since it has been revealed that the majority of people involved in suburbanization previously lived in one of the crowded housing estates in Miskolc, in the immediate neighborhood of heavily polluting industrial plants. Empirical results also show that suburban residents are least satisfied with job opportunities and their financial position, while they are most satisfied with healthcare services, natural environment and public transport. Therefore, it can be concluded that a significant portion of people involved in suburbanization was attracted by the favorable environmental and transport conditions of suburban settlements, low property prices and by benefits offered by local governments. Finally, it has been found that suburban settlements only provide basic services (e.g. family doctor, pharmacy), thus local residents usually use higher-level services (e.g. banking, shopping) in Miskolc.

Nowadays the villages and towns (e.g. Onga, Alsóand Felsözsolca, etc.) of the eastern parts of the suburbia around Miskolc, where low status in-migrants settled down, are struggling with serious socio-economic problems. By the middle or end of the first decades of the 21st century the driving forces of suburbanization were exhausted. Due to the loss of dynamism of suburbanization, a suburban society and economy with lost dynamism and orientation can be observed today. Further development of suburban settlements is chiefly determined by the development of Miskolc, primarily with respect to its labour demand, commuting and residential areas. As a result, further research is needed to explore the highly complex relationships between economic and social factors affecting the evolution of the Miskolc agglomeration in the future. Moreover, the scope of the research should be broadened in the future to compare the results to other, relatively more or less similar Hungarian or other post-socialist agglomerations. 


\section{References}

Bajmócy, P. (2003). Szuburbanizáció a budapesti agglomeráción kívüli Magyarországon [Suburbanization in Hungary outside the Budapest agglomeration]. Doktori értekezés tézisei [PhD Thesis] (in Hungarian).

Brake, K. (2001). Neue Akzente der Suburbanisierung. Suburbaner Raum und Kernstadt: Profile und neuer Verbund. In: Brake, K., Dangschat, J., Herfert, G. (eds.) Suburbanisierung in Deutschland. Aktuelle Tendenzen. Springer Fachmedien, Wiesbaden, 1526 pp. (in German)

Brake, K., Dangschat, J.S., \& Herfert, G. (2001). Suburbanisierung in Deutschland. Aktuelle Tendenzen. Wiesbaden: Springer Fachmedien. (in German). doi:10.1007/978-3-663-11566-3_1

Csanádi, G., \& Csizmady, A. (2002). Suburbanization and society. Tér és Társadalom, 3, 27-55. (in Hungarian).

Csanádi, G., \& Csizmady, A. (2005). Hogyan látjuk a kiköltözöket? [How do we see the move?]. (pp. 1-25). ELTE

- Város és Regionális Kutatások Központja. Mühelytanulmányok [Working Papers] (in Hungarian).

Csanádi, G., Csizmady, A., Kocsis, J., Kőszeghy, L., \& Tomay, K. (2010). City-Planner-Society. Budapest: Sík Kiadó. pp. 471; (in Hungarian).

Dövényi, Z., \& Kovács, Z. (1999). A szuburbanizáció térbeni-társadalmi jellemzői Budapest környékén [Socio-spatial characteristics of suburbanization around Budapest]. Földrajzi Értesítö, 48(1-2), 33-57. (in Hungarian).

Dövényi, Z., \& Kovács, Z. (2006). Budapest: the postsocialist metropolitan periphery between 'catching up' and individual development path. European Spatial Research and Policy, 13(2), 23-41.

Enyedi, (. (1984). The cycle of urbanization and the transformation of the Hungarian settlement network. Budapest: Akadémiai Kiadó. (in Hungarian with English summary).

ESPON. (2012). The Attractiveness of European Regions and Cities for Residents and Visitors. http://www. espon.eu/export/sites/default/Documents/Projects/ AppliedResearch/ATTREG/FR_20130123/01_Sci entific_report_REV.pdf.

Fórizs, M. (1967). Városok körül kialakult településegyüttesek Magyarországon [Settlement groups around cities in Hungary]. Demográfia, 1, 55-70. (in Hungarian).

Hardi, T. (2012). Agglomerations of Győr, Pécs and Miskolc in the rural suburbanization. In P.E. Somlyódyné (Ed.), Special questions of institutionalizing agglomeration. (pp. 15-41). Pécs. (in Hungarian with English summary).
HCSO. (2014). Magyarország településhálózata 1. (pp. 15-18). Budapest: Központi Statisztikai Hivatal. (in Hungarian).

Kókai, S. (2006). Suburbanizing processes in the Nyiregyháza settlement group revisited. (pp. 168-188). Szombathely: Településföldrajzi Tanulmányok. (in Hungarian).

Kőszegfalvi, (. (1979). Az agglomerálódási folyamat kritériumai. Az agglomerációk szerkezetének néhány jellemző sajátossága [Criteria for the agglomerating process. A few characteristic feature of the structure of agglomerations]. In P.I. Kovács \& J. Rechnitzer (Eds.), Az agglomeráció-kutatás módszertani kérdései [Methodological issues of researching agglomerations]. (pp. 67-71). Pécs: MTA DTI. (in Hungarian).

Kovács, T. (2003). Miskolc agglomeration. Miskolc: HCSO. (in Hungarian).

Kovács, T., \& Tóth, G. (2003). Agglomerations, settlement groups in the Hungarian settlement network. Területi Statisztika, 387-391. (in Hungarian).

Kristóf, A. (2017). Functional, sectoral and regional transformation of the economy of the Miskolc Agglomeration revisited. (pp. 84-97). Analele Universităţii din Oradea: Seria Geografie 1.

Kristóf, A. (2017). The Development Path of the Miskolc Agglomeration (1970-2015). Acta Universitatis Sapientiae, European and Regional Studies, 12(1), doi:10.1515/auseur-2017-0006

Ladányi, J., \& Szelényi, I. (1997). Szuburbanizáció és gettósodás [Suburbanization and Ghettos]. Kriti$k a, 7,4-12$. (in Hungarian).

Lukács, J., \& Perger, F. (1975). Egy változat az agglomeráció jelenlétének és körének kimutatására Miskolc és környékének adatai alapján [A possible way to detect the presence and extension of the agglomeration on the basis of data on Miskolc and surrounding areas]. Területi Statisztika, 1, 24-31. (in Hungarian).

Miskolc ITS. (2013). Miskolc Integrated Settlement Strategy - Situation analysis. (in Hungarian with English summary).

Pálné, I., \& Rechnitzer, J. (1982). Agglomeration I. Budapest: Akadémiai Kiadó.

Perczel, G. (2003). Magyarország társadalmi-gazdasági földrajza [Social and economic geography of Hungary]. Budapest: ELTE Eötvös Kiadó. in Hungarian.

Perczel, K. (1964). A regionális tervezés és városrendezés fejlődése Magyarországon 1945-től napjainkig [The development of regional and urban planning in Hungary from 1945 to present]. Városépités, 1, 4-7. (in Hungarian). 
Schuchmann, J. (2013). Residential suburbanizing processes in the Budapest agglomeration. $\mathrm{PhD}$ thesis (in Hungarian with English summary).

Süli-Zakar, I. (1989). Agglomerationsprozesse und ihre Fragezeichen in dem Borsoder Industriegebiet. Acta Geographica Debrecina, 199-211. (in German).

Szántó, Z. (1979). Funkcionálisan együttélő településcsoportok [Functionally coexisting settlement groups]. Településtudományi Közlemények, 1, 41-60. (in Hungarian).

Timár, J. (1999). Elméleti kérdések a szuburbanizációról [Theoretical questions about suburbanization]. Földrajzi Értesítö, 1-2, 7-32. (in Hungarian with English summary).

Timár, J. (2006). Az agglomerálódástól a szuburbanizációig: “Tértermelés" a posztszocialista Magyarországon [From agglomerating to suburbanization: Production of space in post-socialist
Hungary]. In T. Csapó \& Z. Kocsis (Eds.), Agglomerációk és szuburbanizálódás Magyarországon. (pp. 35-51). Szombathely: Savaria University Press. (in Hungarian).

Tóth, G. (2014). Az agglomerációk, településegyüttesek lehatárolásának eredményei. Területi Statisztika 3, 289-299. (in Hungarian with English summary).

Tóth, J. (2006). Stages of agglomerating. In T. Csapó \& Z. Kocsis (Eds.), Agglomerations and suburbanization in Hungary. (pp. 6-14). Szombathely. (in Hungarian with English summary).

Van den Berg, L., Drewett, R., Klaasen, L.H., Rossi, A., \& Vijverberg, C.H. (1982). Urban Europe: A study of growth and decline. Oxford: Pergamon.

Váti Kht. (2001). Identification of the hypothetical agglomeration of Miskolc. Budapest: VÁTI Kht. (in Hungarian with English summary). 